\title{
Factors Affecting Activity-Based Costing Adoption in Autonomous Public Universities in Vietnam*
}

\author{
Thi Bich Ngoc HOANG ${ }^{1}$, Duc Hieu PHAM², Thi Minh Giang NGUYEN ${ }^{3}$, Thi Thanh Phuong NGUYEN ${ }^{4}$
}

Received: September 10, 2020 Revised: November 08, 2020 Accepted: November 16, 2020

\begin{abstract}
The main aim of the present study is to investigate the factors that are considered affecting the adoption of Activity-Based Costing (ABC) in the autonomous public universities in Vietnam. A quantitative research was carried out. The data was collected through an online questionnaire survey between June 2020 and September 2020 addressed to the target respondents comprising 168 managers and accountants from 23 autonomous public universities in Vietnam, which participated in the resolution project No. 77/NQ-CP of the Vietnamese government on the pilot renovation of operational mechanisms of public tertiary education institutions during the period of four years, from 2014 to 2017 . The findings resulted from hypothesis testing by a binary regression analysis based on the SPSS 20.0 software show that training, competition, support of top manager, and university size are the four main factors that positively affect the adoption of Activity-Based Costing (ABC) in studied universities. On the other hand, no statistically significant impact was found on two other variables, namely the variety of services provided and the usefulness of cost information factors. From the research results, discussions and policy recommendations have been presented to promote the adoption of Activity-Based Costing ( $\mathrm{ABC}$ ) in Vietnamese autonomous public universities in the coming time.
\end{abstract}

Keywords: Activity-Based Costing, Adoption, Autonomous Public Universities, Factors, Vietnam

JEL Classification Code: I28, M10, M40, M41

\section{Introduction}

Activity-based costing (ABC) was first introduced in the late 1980s by Johnson and Kaplan. ABC has corrected serious deficiencies in traditional standard-costing systems. $\mathrm{ABC}$ is considered the greatest innovation in management accounting in the $21^{\text {st }}$ century (Grondskis \& Sapkauskiene,

\footnotetext{
*Acknowledgments:

The authors would like to thank anonymous referees for their constructive comments on the earlier version of this paper.

${ }^{1}$ First Author. Lecturer, Department of Managerial Accounting, Thuongmai University, Vietnam. Email: bichngocdhtm@tmu.edu.vn

${ }^{2}$ Corresponding Author. Lecturer, Department of Auditing, Thuongmai University, Vietnam [Postal Address: 79 Ho Tung Mau Street, Cau Giay District, Hanoi, 122868, Vietnam]

Email: hieu.pd@tmu.edu.vn

${ }^{3}$ Lecturer, Department of Managerial Accounting, Thuongmai

University, Vietnam. Email: minhgiangktcb@gmail.com

${ }^{4}$ Lecturer, Department of Financial Accounting, Thuongmai

University, Vietnam. Email: thanhphuongkttc@gmail.com

(c) Copyright: The Author(s)

This is an Open Access article distributed under the terms of the Creative Commons Attribution Non-Commercial License (https://creativecommons.org/licenses/by-nc/4.0/) which permits unrestricted non-commercial use, distribution, and reproduction in any medium, provided the unrestricted non-commercial work is properly cited.
origal
}

2011). Since its introduction, $\mathrm{ABC}$ has attracted the attention of many academics and accounting practitioners. ABC has emerged as an important tool in business. Gradually, ABC has penetrated into non-profit organizations including higher educational institutions. Research on $\mathrm{ABC}$ is mainly focused in manufacturing, and then developed into the service and public sectors (Bjørnenak \& Mitchell 2002). Although the empirical evidence supports ABC's positive role in improving firm operations, productivity and profitability, the adoption of $\mathrm{ABC}$ on a global scale is not high (Charaf \& Bescos, 2013). The prior research results are true for both industry and education and training services. Researchers found that $\mathrm{ABC}$ adoption rates are higher in developed countries than in developing countries (Charaf \& Bescos, 2013).

Vietnam is a country with a transition economy, which has made remarkable achievements in economic growth. In recent years, the need for integration and globalization in the educational sector has increased the competitive pressure on public universities in Vietnam. On the other hand, the policy of increasing autonomy for public universities, and the reduced funding from the State budget has forced these universities to consider changing the cost accounting system to provide useful information for decision-making. 
The study aims to: (1) investigate if $\mathrm{ABC}$ is considerate adoption in the autonomous public universities in Vietnam; (2) identify the factors affecting ABC adoption in Vietnamese autonomous public universities; and (3) propose solutions to promote $\mathrm{ABC}$ adoption in autonomous public universities in Vietnam in the coming time.

The structure of the study is as follows: The next section presents a review of literature on $\mathrm{ABC}$ adoption in organizations, followed by research hypothesis development. The third section presents research methodology including measurement scale, questionnaire design, target respondents and sample, and data analysis. Then, the research results are presented in the fourth section. Finally, the fifth section ends the paper with discussion and recommendations.

\section{Literature Review and Research Hypotheses}

\subsection{Literature Review}

ABC adoption in enterprises has been studied for a long time. Several studies have addressed various aspects of the $\mathrm{ABC}$ systems, providing insights into the use of $\mathrm{ABC}$ in specific sectors, examining the significance of alternative factors on adopting $\mathrm{ABC}$ and the impact of $\mathrm{ABC}$ implementation on the organizations. The focus of this review is on issues discussed by previous studies relevant to $\mathrm{ABC}$ adoption in organizations.

Studies on the ABC adoption show that there is a difference in the $\mathrm{ABC}$ adoption rate between countries globally. In the UK, Innes, Mitchell and Sinclair (2000) reported that 17.5 per cent of firms actually implemented ABC, while Tayles and Drury (2001) reported a 23 per cent diffusion rate. Bhimani et al. (2007) conducted a cross national survey in seven countries and found that the proportion of respondents using $\mathrm{ABC}$ across business units is as follows: Canada (39.1 per cent), France (21.6 per cent), Germany (50 per cent), Italy ( 26.3 per cent), UK (55.8 per cent), US (54.4 per cent), and Japan (6.1 per cent). These results cannot be compared with each other because of some differences in the authors' approach to the studies. According to Aldukhil (2012), the differences in results may be attributed to the differences in survey questions. Some researchers may include in the adoption rate firms that intend to implement $\mathrm{ABC}$ in the future or firms that have already discontinued it. Further, some researchers may investigate the extent of $\mathrm{ABC}$ adoption rather than a dichotomous indication of $\mathrm{ABC}$ adoption (Krumwiede, 1998; Aldukhil, 2012). Also, some researchers do not differentiate between $\mathrm{ABC}$ and $\mathrm{ABM}$ while others do (Aldukhil; 2012).

Research on the $\mathrm{ABC}$ adoption based on theories such as contingency theory (Al-omiri, 2012; Brierley, 2009; Rankin, 2016), diffusion innovation theory, and strategic management theory (Gosselin, 1997; Baird et al., 2004). Theory can be used alone or in combination with others, for example of Rankin (2016) using a combination of innovation theory and strategic management, research by Al-omiri (2003) and Aldukhil (2012) using a combination of the contingency theory and diffusion innovation. Whatever the theoretical approach may be but the factors that are taken into consideration are the factors that make an effect on $\mathrm{ABC}$ adoption including technical factors, behavioral factors and organizational factors. Researchers have explored factors that influence $\mathrm{ABC}$ implementation such as top management support, linkages to competitive strategy, training and consensus, and clarity regarding $\mathrm{ABC}$ objectives (Shields 1995). Shields (1995) found that successful implementation of $\mathrm{ABC}$ is associated with behavioral and organizational factors. These factors are top management support, linkages to competitive strategies, linkages to performance evaluation and compensation, training in implementing $\mathrm{ABC}$, nonaccounting ownership, and adequate resources.

Anderson and Young (1999) found that ABC success is influenced by contextual and process variables, including top management and union support of the $\mathrm{ABC}$ project, adequacy of resources, individual commitment to the organization, the likelihood of lay-offs, and the degree to which good performance is expected to be rewarded. Anderson (1995) points out that some factors including individual, organizational, technology, task and environmental factors have different impacts among the various stages. Askarany and Smith (2004) found that the diffusion of six innovations including $\mathrm{ABC}$ is positively associated with employee awareness of the benefits of an innovation, employee awareness of the availability of an innovation, management commitment on implementation of an innovation, the employment of consultants to facilitate implementation of an innovation, and negatively associated with the lack of confidence in the new cost accounting technique.

$\mathrm{ABC}$ is a private sector innovation, which has been successfully implemented and also used in the public sector and universities (Cropper \& Cook, 2000). Until now, there is not one complete statistical work on $\mathrm{ABC}$ research in the education sector. A very few studies were devoted to non-profit organization, especially with higher education institutions. However, the research of Sumrall (2019) shows that $\mathrm{ABC}$ adoption in universities globally has received limited attention. In the education and training sector worldwide, the adoption rate is reported to be just 9.7\% (Aldukhil, 2012). According to Ismail (2010) and Aldukhil (2012) most of the applications of $\mathrm{ABC}$ before 2000 were in the Englishspeaking world: Australia, Canada, Great Britain, Hong Kong, and the U.S. However, this is certainly not the case as of 2019 where several research projects have been conducted worldwide since 2000 (Sumrall, 2019). These include survey studies on ABC in UK universities (Al-omiri \& Drury, 2007; 
Cropper \& Cook, 2000), in Australian universities (EllisNewman, 2003), in Malaysian universities (Ismail, 2010), in Estonian universities (Kont, 2011).

The studies focus on $\mathrm{ABC}$ adoption in specific universities so that the case study method is mainly used. An interesting observation of these studies was the choice of university departments and libraries. These include the researchs in Australia (Ellis-Newman, 2003), in UK (Goddard \& Ooi, 1998), and in Estonia (Kont, 2011). ABC is ideally suited for use in academic libraries because library activities are distinct and separable. Research regarding the factors affecting on the $\mathrm{ABC}$ adoption among universities is quite limited. Madwe et al. (2020) reported the awareness of and attitudes towards $\mathrm{ABC}$ held by finance staff of six technical and vocational educating and training (TVET) colleges in KwaZulu-Natal, South Africa proposed a novel model for its successful adoption. Approach on the contingency theory, the behavioral and organizational factors as well as the technical factors are tests of factors affecting the $\mathrm{ABC}$ adoption at the colleges. The study points out that lack of top managers' support, the colleges' cost structure and technical factors are barriers to the implementation of $\mathrm{ABC}$ in their institutions. The study of Sumrall (2019) determines the extent of $\mathrm{ABC}$ implementation and examines the reasons for the implementation of $\mathrm{ABC}$ in Australian universities. The study points out that $\mathrm{ABC}$ implementers are dominated by larger universities on both counts - number of employees and annual turnover. $\mathrm{ABC}$ adoption and implementation benefits from top management support during both the trial period and post-implementation. Time and cost associated with $\mathrm{ABC}$ implementation is reported as the dominant reason for not implementing ABC. The lack of empirical studies motivates the researchers to do this study on factors that addresses $\mathrm{ABC}$ adoption among universities in Vietnam.

\subsection{Research hypotheses}

The factors proposed in the literature that might affect $\mathrm{ABC}$ adoption are divided into behavioral and organizational factors and technical factors. Behavioral and organizational factors consist of the size of the organization, support of top managers, cost structure, product diversity, resistance to change, the presence of an internal champion and innovation, internal resource availability, and training. Technical factors consist of identifying activities, grouping and aggregating these activities, assigning resources and costs to these activities and objects, and selecting cost drivers of indirect costs. In this study, some predicted behavioral and organizational factors are discussed in turn.

\section{University size (QM)}

Organizational size is a factor included in most research models on $\mathrm{ABC}$ adoption in business organizations (Gosselin, 1997; Al-omiri, 2003; Brierley, 2009; Rankin,
2016) or in university (Madwe et al., 2020; Nguyen, 2020). Studies have found a positive relationship between ABC adoption and organization scale. According to Moores and Chenhall (1994), there are some reasons for this relationship including: (i) the demand for management information for planning, control and coordination activities is greater in larger organizations; (ii) larger organizations are more able to commit resources to the development and implementation of activity management practices; and (iii) the more resources are available to activity management practices, the better those practices are likely to be and the higher their perceived benefits. The size of the university determines the size of the resources used, the techniques of cost allocation. Universities with large scales often have larger cost scales and more complex cost-allocation techniques than the small universities. Hence:

H1: University size affects the adoption of $A B C$ in autonomous public universities in Vietnam.

\section{Competition (CT)}

Many previous studies have identified a positive relationship between the competition in the market and the use of a management accounting system. Regarding product costing, it is suggested that when there is a high level of competition, companies should implement $\mathrm{ABC}$ (Kaplan \& Cooper, 1998; Pham et al., 2020). Therefore, it can be expected that an organization facing a high level of competition will consider adopting $\mathrm{ABC}$. In recent years, Vietnam has participated in the General Agreement on Trade and Services (GATS) - the Agreement to ensure free access to the education market. It has led to the Vietnamese public universities facing fierce competition. Hence:

H2: The competition positively affects the adoption of $A B C$ in autonomous public universities in Vietnam.

\section{Support of the top manager (HT)}

The role of top manager in $\mathrm{ABC}$ implementation has been studied by many authors (Aldukhil, 2012; Madwe et al., 2020; Pham et al., 2020). In an organization, top manager has the role of determining the vision and policy, making decisions, solving problems, driving the organization to growth and survival and motivating all employees involved in the application of the accounting system. Thus, the awareness and support of top managers ensure the successful application of new accounting systems such as $\mathrm{ABC}$ for an organization. Success is more likely to be achieved when top managers support $A B C$ adoption (Aldukhil, 2012; Elagili, 2015). The support of top managers is not only necessary in the early stages of $\mathrm{ABC}$ implementation but also an ongoing process for maintaining new systems (Aldukhil, 2012). Hence: 
H3: The support of top managers affects the $A B C$ adoption in autonomous public universities in Vietnam.

\section{ABC Training (DT)}

Training aims to provide knowledge and transfer experiences to help employees in the organization develop a positive attitude when being introduced to ABC. Training provides knowledge of designing, implementing and using $\mathrm{ABC}$ to organizations. Therefore, training is a prerequisite factor to ensure that employees understand the benefits of the system and help them make decisions (Elagili, 2015). Elagili (2015) points out that it is necessary to have training and promotion programs for administrative staff, followed by implementers and users. Hence:

H4: Training positively affects the ABC adoption in autonomous public universities in Vietnam.

\section{Variety of services provided (DD)}

Empirical studies have reported on the relationship between product diversity and ABC adoption. According to Schoute (2011), product diversity is also a major factor in ABC adoption. Krumwiede (1998) found a positive association between product diversity and $\mathrm{ABC}$ adoption, indicating that $\mathrm{ABC}$ adoption is higher among firms with higher product diversity. However, Clarke, Hill and Stevens (1997) found a negative relationship between product diversity and $\mathrm{ABC}$ adoption. Universities providing a variety of courses will need precise cost allocation, therefore, they are more likely to adopt ABC. Hence:

H5: The variety of services provided affects the $A B C$ adoption in autonomous public universities in Vietnam.

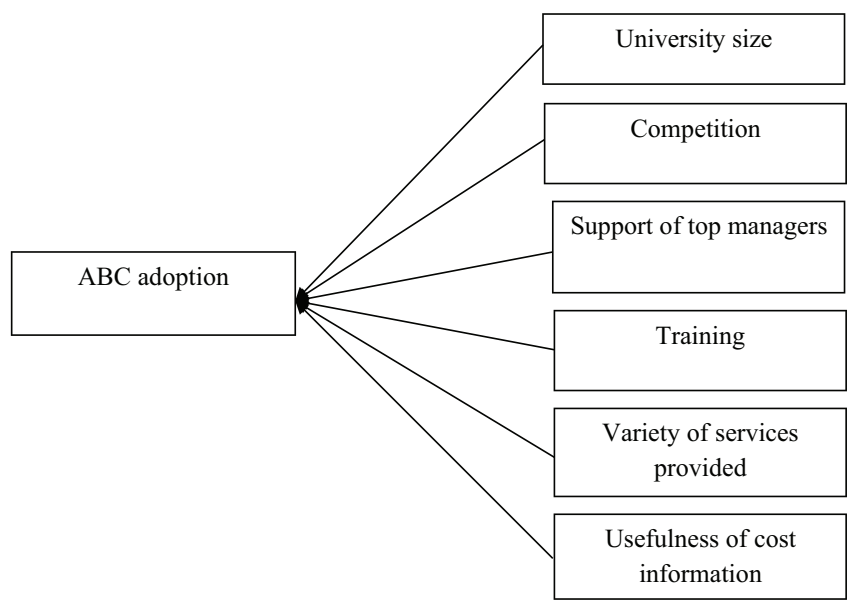

Figure 1: The research model

\section{Usefulness of cost information (HI)}

The usefulness of cost information has been studied by (Gosselin, 1997; Baird et al., 2004; Rankin, 2016). Information is useful if it helps managers make decisions. Therefore, the organization will be able to adopt ABC if it creates the information system used in decision making. $\mathrm{ABC}$ has corrected serious deficiencies in traditional standard-costing systems. However, organizations are only expected to adopt $\mathrm{ABC}$ if it will generate information that will be used in decision-making. Krumwiede (1998) said that even if $\mathrm{ABC}$ will reduce cost distortions substantially, it probably will not be implemented unless a company can use the better cost in its decision making. Hence:

H6: The usefulness of cost information affects the $A B C$ adoption in public universities in Vietnam.

The research model presented below summarizes the hypotheses on factors affecting $\mathrm{ABC}$ adoption in public universities in Vietnam.

\section{Research Method}

Survey method was used in this study. Survey method was proposed by Young and Selto (1991) to develop and test theories related to changes in management accounting information. The survey method is commonly used in business studies and is consistent with previous ABC-related studies.

\subsection{Measurement Scales}

The measurement scales are based on original studies (Gosselin, 1997; Krumwiede, 1998; Al-omiri \& Drury, 2007; Brierley, 2009; Aldukhil, 2012; Rankin, 2016; Nguyen, 2020; Nguyen, 2020; Pham et al., 2020) and developed by the researcher for the research context in autonomous public universities.

Dependent variable (ABC adoption - KN): Respondents were asked to answer the question regarding $\mathrm{ABC}$ adoption in their university. The ABC adoption was obtained from a single question with responses of current $\mathrm{ABC}$ adoption (not-adopted or adopted). For the purposes of the binary regression analysis, a response with $\mathrm{ABC}$ adoption is coded as ' 1 ' and a response with non-adoption is coded as ' 0 '.

Independent variables: The 5-point Likert scale is used to measure independent variables. Six independent variables of the study were measured through 20 questions. Each question was presented as a statement and respondents were asked to indicate the extent to which they agree with each statement on a 5-point Likert scale, anchored on 1 for strongly disagree and 5 for strongly agree. The details of independent variables are presented as follows: 
University size (QM) is measured by the average score of 3 questions developed by the researcher, covering the number of students, the number of full-time employees, and the revenues of the university.

The usefulness of cost information (HI) is measured by the average score of 4 questions about the use of cost information for making decisions in the university. That includes cost information for short-term decisions, cost information for long-term decisions, cost information for performance evaluation decision, and cost information for pricing purposes.

The variety of services provided (DD) is measured by the average score of 3 questions, including the variety of training systems, the diversity of training degrees, and the diversity of training programs.

The support of top managers (HT) is measured by the average score of 3 questions, relating to sufficient resource provision, implementation support, and performance support.

Training (DT) is measured by the average score of 4 questions, focusing on the role of $\mathrm{ABC}$, the design of $\mathrm{ABC}$, the implementation of $\mathrm{ABC}$, and the use of $\mathrm{ABC}$.

Competition (CT) is measured by a composite scale constructed averaging the responses for 3 questions, including tuition fee, number of competitors, and prestige and reputation of the university.

The pilot questionnaire was firstly tested by a small group of managers and accountants in the University of Commerce and subsequently completed and distributed widely by email to accountants and managers at 23 autonomous public universities in Vietnam.

\subsection{Questionnaire Design}

The target respondents are both managers and accountants at 23 autonomous public universities in Vietnam. Generally, managers decide to adopt or not to adopt $\mathrm{ABC}$ and rely on information related to $\mathrm{ABC}$ for their making decisions. Accountants are responsible for designing and implementing $\mathrm{ABC}$ in the organization. Therefore, the survey on perceptions of both managers and accountants expects to reflect accurately the extent of $\mathrm{ABC}$ adoption in autonomous public universities. In total, there are 250 distributed questionnaires between June 2020 and September 2020; the collected number is 168 , at a rate of $67.2 \%$.

\subsection{Data Analysis}

After cleaning the data, researchers use SPSS version 20.0 to analyze data. Firstly, Cronbach's alpha is calculated to measure the internal consistency of the scale. Then, Exploratory Factor Analysis (EFA) is run to test the relatively scale, determine the model's suitability indicators as well as calculate and verify the reliability indicators of the scale. When the scale indicators are satisfactory, a regression analysis is carried out. The binary regression model is used with dependent variable being $\mathrm{ABC}$ adoption $(\mathrm{KN})$, independent variables including university size $(\mathrm{QM})$, training (DT), usefulness of cost information (HI), competition (CT), support of top managers (HT), and variety of services provided (DD). The regression model is as follows:

$$
\begin{aligned}
\log \left[\frac{P_{i}}{1-P_{i}}\right] & =\mathrm{B}_{0}+\mathrm{B}_{1} \mathrm{QM}+\mathrm{B}_{2} \mathrm{DT}+\mathrm{B}_{3} \mathrm{HI} \\
& +\mathrm{B}_{4} \mathrm{CT}+\mathrm{B}_{5} \mathrm{HT}+\mathrm{B}_{6} \mathrm{DD}
\end{aligned}
$$

Where: $P_{i}$ : Probability of $\mathrm{ABC}$ adoption; $\mathrm{B}_{0}, \mathrm{~B}_{1}, \mathrm{~B}_{2}, \mathrm{~B}_{3}$, $\mathrm{B}_{4}, \mathrm{~B}_{5}, \mathrm{~B}_{6}$ : Regression coefficient; and QM, DT, HI, CT, HT, DD: Independent variables.

\section{Results and Discussion}

\subsection{Reliability Analysis}

Cronbach's alpha is used to measure the internal consistency of the scale. The final results show that among 6 independent variables, there are 5 variables which have Cronbach's alpha greater than 0.7 and less than 9.5, only support of top managers variable receives Cronbach's alpha of 0.636. Nunnally (1978) and Peterson (1994) suggest that Crobach's alpha equal 0.6 or higher is usable in cases where the measurement concept or the context of the study is new for the respondents. The measurement scale of top managers' support is not a new concept in $\mathrm{ABC}$ studies in the industrial sector, but for the educational sector, it is quite new. Therefore, Cronbach's alpha at 0.636 is considered reliable. These results indicate that the initial scales ensure validity and reliability.

\subsection{Exploratory Factor Analysis (EFA)}

The results of exploratory factor analysis (Table 1) shows that $\mathrm{KMO}$ coefficient $=0.694$ is suitable for factor analysis, Bartlett's Test has sig $=0.00<0.05$, showing the correlation of the observed variables in the same factor. Using Extraction Method of Principal Component Analysis and the Rotation Method of Varimax with Kaiser Normalization for the analysis of the independent variables embraced in the model, it was found that six factors are extracted at Eigenvalue $=1.488>1$. Furthermore, since total variance extracted $=61.148 \%>50 \%$ shows the EFA model is appropriate. Hence, the six extracted factors will explain $61.148 \%$ of the variability of the observation. 
Table 1: KMO and Bartlett's Test

\begin{tabular}{|l|l|c|}
\hline \multicolumn{2}{|l|}{ Kaiser-Meyer-Olkin Measure of Sampling Adequacy } & .654 \\
\hline \multirow{3}{*}{ Bartlett's Test of Sphericity } & Approx. Chi-Square & 759.191 \\
\cline { 2 - 3 } & Df & 190 \\
\cline { 2 - 3 } & Sig. & .000 \\
\hline
\end{tabular}

Table 2: Results of Binary regression

\begin{tabular}{|c|c|c|c|c|c|c|c|}
\hline & & B & S.E. & Wald & df & Sig. & $\operatorname{Exp}(B)$ \\
\hline \multirow{7}{*}{ Step $1^{a}$} & QM & .584 & .222 & 6.905 & 1 & .009 & 1.794 \\
\hline & DT & 1.214 & .327 & 13.744 & 1 & .000 & 3.367 \\
\hline & $\mathrm{HT}$ & .885 & .258 & 11.764 & 1 & .001 & 2.422 \\
\hline & $\mathrm{HI}$ & .458 & .548 & .699 & 1 & .403 & 1.581 \\
\hline & CT & 1.081 & .500 & 4.671 & 1 & .031 & 2.948 \\
\hline & DD & .342 & .461 & .549 & 1 & .459 & 1.407 \\
\hline & Constant & -17.993 & 4.348 & 17.122 & 1 & .000 & .000 \\
\hline & & ariable(s) & on ste & $\mathrm{M}, \mathrm{DT}, \mathrm{H}$ & DD & & \\
\hline
\end{tabular}

\subsection{Multiple Regression Analysis}

The study uses binary regression to test hypotheses about the influence of factors on $\mathrm{ABC}$ adoption in autonomous public universities in Vietnam. The results of the Binary Regression analysis showed that Chi-square $=50.232$, Sig $=0.00<0.05,-2$ Log likelihood $=87.567$ are statistically significant. Thus, the model is significant and qualified for further assessment.

Table 2 provides Binary regression results. The study finds that four variables QM, DT, HT, and HI have a significant and positive impact on the $\mathrm{ABC}$ adoption in the organization. Thus, hypothesis $\mathrm{H} 1, \mathrm{H} 2, \mathrm{H} 3$, and $\mathrm{H} 4$ are accepted with significance at $5 \%$. On the other hand, the study does not find any significant relationships for the remaining variables: DD and $\mathrm{HI}$ since Sig. values are 0.459 and 0.403 respectively and greater than 0.05 . Hence, hypotheses H5 and H6 are not supported. Consequently, the results of Binary regression analysis can be presented as follows:

$$
\begin{gathered}
\log \left[\frac{P_{i}}{1-P_{i}}\right]=-17.993+0.584 \mathrm{QM}+1.214 \mathrm{DT} \\
+1.081 \mathrm{CT}+0.885 \mathrm{HT}
\end{gathered}
$$

The results show that training, competition, management support, and university size all positively affect the $A B C$ adoption; among them training variables the strongest impact, followed by competition, management support, and finally university size.

\section{Conclusion and Recommendations}

\subsection{Conclusion}

Research results point out that $\mathrm{ABC}$ adoption is significantly affected by training, competition, support from top managers, and size of the university. These findings are consistent with previous studies on $\mathrm{ABC}$ adoption in the business sector (Kaplan \& Cooper, 1998, Krumwiede, 1998; Aldukhil, 2012; Rankin, 2016). Compared with previous studies in the educational sector, the findings are consistent with Sumrall (2019), but in contradiction to Madwe et al. (2020). From this result, once again, the study confirms that training activities are very necessary for the success in application of innovations in accounting. The level of competition is also reflected in the actual operating environment of Vietnamese universities. The competition for higher education in Vietnam increased when the country became an official member of the WTO, signed the General Agreement on Trade and Services (GATS) ensuring free access to the education market that encompasses all types of educational products and educational institutions.

On the other hand, the autonomous mechanism allows universities to be more autonomous in operation, but also puts the universities in a situation of greater competition due to reduced funding by the government. Therefore, they need new tools for more accurate cost allocation to increase competitiveness. The support from top managers is one of the decisive factors for the success or failure of $\mathrm{ABC}$ application. 
$\mathrm{ABC}$ implementation requires strong commitment from top management to provide sufficient resources and motivation for the project in all its phases. However, the non-significant effect of services variety and usefulness of the cost information are in contradiction to findings of Kaplan and Cooper (1998), Krumwiede (1998), Aldukhil (2012), Rankin (2016), Sumrall (2019), and Madwe et al. (2020). It is explained that making decisions is strongly influenced by State regulations in Vietnamese autonomous public universities. The cost information provided by the accountant is used for reference only as It is, in fact, is not a decisive factor in the decisionmaking process.

\subsection{Recommendations}

The research results suggest some recommendations in promoting $\mathrm{ABC}$ adoption in autonomous public universities in Vietnam. For the universities, the $A B C$ training programs should be organized to raise awareness for managers at all levels and to update the knowledge for accountants. As the education service providers, the universities should coordinate with the Vietnam Association of Accounting and Auditing (VAA) to update the accounting curriculum to provide students with professional knowledge and skills for readiness of $\mathrm{ABC}$ implementation. For the government, the $\mathrm{ABC}$ communication projects in public institutions including universities should be implemented. Besides, the government should reduce its intervention and further promote autonomy mechanisms in public universities.

The present study cannot avoid some limitations. The results are limited to autonomous public universities; therefore, they cannot be generalized to other fields such as private universities in Vietnam. Moreover, because of a small sample size, the findings cannot be representative of the whole country. The limitations of the study will be improved if the sample is randomly selected and more complete technical and contextual variables are added in the future research model.

\section{References}

Aldukhil, Y. (2012). Developing and Testing a Model of Successful Adoption of Activity-Based Costing. Doctoral dissertation, Victoria University.

Al-Omiri, M. (2003). The diffusion of management accounting innovations: a study of the factors influencing the adoption, implementation levels and success of $A B C$. Doctoral dissertation, University of Huddersfield.

Anderson, S. W., \& Young, S. M. (1999). The impact of contextual and process factors on the evaluation of activity-based costing systems. Accounting, Organizations and Society, 24(7), 52559. DOI:10.1016/S0361-3682(99)00018-5
Anderson, S. (1995). A framework for assessing cost management system changes: The case of activity based costing implementation at General Motors, 1986-1993. Journal of Management Accounting Research, 7, 1-51.

Askarany, D., \& Yazdifar, H. (2012). An investigation into the mixed reported adoption rates for $\mathrm{ABC}$ : evidence from Australia, New Zealand and the UK. International Journal of Production Economics, 135, 430-439. DOI:10.1016/j.ijpe.2011.08.017

Baird, K., Harrison, G., \& Reeve, R. (2004). Adoption of activity management practices: A note on the extent of adoption and the influence of organizational and cultural factors. Management Accounting Research, 15, 383-399. DOI:10.1016/j.mar.2004. 07.002

Bhimani, A., Gosselin, M., Ncube, M. \& Okano, H. (2007). ActivityBased Costing: How Far Have We Come Internationally? Journal of Cost Management, 21(3), 12-7.

Bjørnenak, T., \& Mitchell, F. (2002). The Development of Activity-Based Costing Journal Literature, 1987-2000. The European Accounting Review, 11(3), 481-508. DOI:10.1080/ 0963818022000001019

Brierley, J. A. (2009). Toward an understanding of the sophistication of product costing systems. Journal of Management Accounting Research, 20, 61-78. DOI:10.1.1.566.8624

Charaf, K., \& Bescos, P. (2013). The role of organizational and cultural factors in the adoption of activity-based costing: the case of Moroccan firms. Accounting and Management Information Systems, 12(1), 4-21. DOI:10.1.1.566.8624

Cropper, P., \& Cook, R. (2000). Developments: activity-based costing in universities - five years on. Public Money \& Management, 20(2), 61-8. DOI:10.1111/1467-9302.00213

Clarke, P., Hill, N., \& Stevens, K. (1999). Activity based costing in Ireland: barriers to, and opportunities for change. Critical Perspectives on Accounting, 10(4), 443-68. DOI:10.1006/ cpac.1997.0197

Ellis-Newman, J. (2003). Activity-based costing in user services of an academic library. Library Trends, 51(3), 333-48.

Elagili, G. (2015). Adoption factors for the implementation of activity based costing systems: A case study of the Libyan cement industry. Doctoral dissertation, University of Salford.

Goddard, A., \& Ooi, K. (1998). Activity-based costing and central overhead cost allocation in universities: A case study. Public Money and Management, 18(3), 31-8. DOI:10.1111/14679302.00124

Grondskis, G., \& Sapkauskiene, A. (2011). Cost accounting information use for product mix design. Economics and Management, 1(1), 48-53.

Gosselin, M. (1997). The effect of strategy and organizational structure on the adoption and implementation of activity-based costing. Accounting, Organizations and Society, 22(2), 105122. DOI: 10.1016/S0361-3682(96)00031-1

Innes, J., Mitchell, F., \& Sinclair, D. (2000). Activity-based costing in the U.K.'s largest companies: A comparison of 
1994 and 1999 survey results. Management Accounting Research, 11(3), 349-62. DOI:10.1006/mare.2000.0135

Ismail, N. (2010). Activity-based management system implementation in higher education Institution. Campus-Wide Information Systems, 27(1), 40-52. DOI:10.1108/10650741011011273

Kaplan, S. \& Cooper, R. (1998). Cost \& Effect: Using Integrated Cost Systems to Drive Profitability and Performance. Harvard Business School Press, Boston.

Krumwiede, K. (1998). The implementation stages of activitybased costing and the impact of contextual and organizational factors. Journal of Management Accounting Research, 10, 239-77.

Kont, K. R. (2011). New cost accounting models in measuring of library employees' performance. Library Management, 33(1), 50-65. DOI:10.1108/01435121211203310

Madwe, M. C., Stainbank, L. J., \& Green, P. (2020). Factors affecting the adoption of activity-based costing at technical and vocational education and training colleges in KwaZulu-Natal, South Africa. Journal of Economic and Financial Sciences, 13(1), 1-10. DOI:10.4102/jef.v13i1.467

Moores. K., \& Chenhall, R. H. (1994). Framework and MCS evidence. In: K. Moores, \& P. Booth (Eds.), Strategic management accounting (pp. 12-26). Hoboken, NJ: Wiley

Nguyen, N. T. (2020). Factors Affecting Responsibility Accounting at Public Universities: Evidence from Vietnam. Journal of Asian Finance, Economics and Business, 7(4), 275-286. https:// doi.org/10.13106/jafeb.2020.vol.no4.275

Nguyen, T. T. (2020). Studying Factors Affecting Environmental Accounting Implementation in Mining Enterprises in Vietnam.
Journal of Asian Finance, Economics and Business, 7(5), 131-144. http://doi.org/10.13106/jafeb.2020.vol.7no.5.131

Nunnally, J. C. (1978). Psychometric theory (2nd ed.). New York, NY: McGraw-Hill.

Peterson, R. A. (1994). A Meta-Analysis of Cronbach's Coefficient Alpha. Journal of Consumer Research, 21, 381-391. DOI: $10.1086 / 209405$

Pham, D. H., Dao, T. H., \& Bui, T. D. (2020). The Impact of Contingency Factors on Management Accounting Practices in Vietnam. Journal of Asian Finance, Economics and Business, 7(8), 77-85. http://doi:10.13106/jafeb.2020.vol7. no.8.077

Rankin, R. (2016). Exploring the relationship among contextual factor on activity-based costing adoption. Doctoral dissertation, North central University.

Shields, M. (1995). An empirical analysis of firms' implementation experiences with activity-based costing. Journal of Management Accounting Research, 7, 148.

Schoute, M. (2011). The relationship between product diversity, usage of advanced manufacturing technologies and activitybased costing adoption. The British Accounting Review, 120134. DOI:10.1016/j.bar.2011.02.002

Sumrall., V. E. (2019). Diffusion of Activity Based Costing (ABC) in Australian Universities: An Exploration of Drivers and Barriers of $A B C$ Adoption. Doctoral dissertation, Charles Darwin University.

Young, S. M., \& Selto, F. (1991). New Manufacturing Practices and Cost Management: a Review of the Literature and Directions for Research. Journal of Accounting Literature, 320-351. 